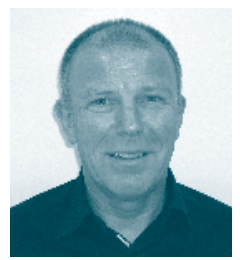

Eirik Roos, sykepleier, MPA rådgiver i rådmannens fagstab, Trondheim kommune.

\title{
Samhandling koster
}

\author{
Kan det være slik at samhandlingen noen ganger kan føre til et utilsiktet resultat \\ som genererer utgifter i stedet for å effektivisere kostnader?
}

$\AA$ samhandle om felles mål er et viktig og anerkjent virkemiddel for å oppnå resultater, det være seg innenfor idretten, prosjektarbeid og mellom ulike aktører. Jeg er rådgiver i Trondheim kommune og har i min masteroppgave studert samhandling mellom aktører i helsevesenet.

\section{Utilsiktet resultat}

Funn fra mitt forskningsprosjekt om samhandling omkring utskrivingsklare pasienter mellom fagpersoner i St. Olavs Hospital og Trondheim kommune kan tyde på et utilsiktet resultat. En gjennomgang av 26 utskrivingsklare pasienter i mai 2008, viste at disse ventet i gjennomsnitt 10,6 måneder på sykehus eller ved distriktspsykiatriske sentre (DPS) på kommunale tjenester, til tross for at de var ferdig med behandlingen. Når jeg benytter gjennomsnittskostnader for sykehus eller DPS, representerer disse pasientene en «unødvendig» sykehus- eller DPS-kostnad på cirka 40 millioner kroner. En nærmere undersøkelse av seks av de 26 utskrivingsklare pasientene fra mai 2008, viser store forskjeller på omfanget av tildelte kommunale tjenester før og etter sykehus- eller DPS-innleggelse for pasienter med en alvorlig psykisk lidelse. Før innleggelse hadde alle pasientene tilgang til bolig, samt ukentlige helse og omsorgstjenester fra Trondheim kommune. Etter at institusjonsbehandlingen var avsluttet bestiller spesialisthelsetjenesten spesifikke kommunale omsorgstjenester, det vil si ny bolig med tilgang til døgnkontinuerlige omsorgstjenester. Kommunens ansatte kopierer bestillingen og fatter kommunale forvaltningsvedtak. Pasientene blir dermed værende på sykehus eller DPS i påvente av at Trondheim kommune tildeler ny bolig og tilgang til døgnkontinuerlige omsorgstjenester.

Funn fra et nytt prosjekt om etterbehandling i kommunalt helsehus av inneliggende pasienter i psykiske helsevern, viser at 13 av 14 pasienter ble utskrevet til egen bolig i løpet av fire ukers opphold ved Leistad (helsehus). En kartlegging av kommunale omsorgstjenester for disse pasientene før og etter opphold i helsehus viser ingen vesentlige endringer.

\section{Virkemiddel}

Er vurderingene av omsorgsbehov og tildeling av flere omsorgstjenester et resultat av pasientens endring i sykdomstilstand eller av konteksten som vurderingene foretas i?

Bakgrunnen for min studie var å finne ut mer om fenomenet «samhandling» i tilknytning til «utskrivingsklare» pasienter. Samhandling benyttes om koordinasjon og gjennomføring av aktiviteter i en prosess der ingen enkelt person eller institusjon har et totalansvar for prosessen. Koordinasjon og gjennomføring av aktivitetene må derfor finne sted i forhandlinger mellom aktørene.
Samhandling er som regel ikke et mål i seg selv, men et virkemiddel. Når jeg bruker begrepet samhandling i min studie er det knyttet til prosessen i forbindelse med møter mellom fagansatte i St. Olavs Hospital, Divisjon psykisk helsevern, og Trondheim kommune, helse og velferd. Det vil si spesifikke møter på sykehuset eller DPS-et som skal avklare om inneliggende pasienter er utskrivingsklare og hvilke omsorgstjenester som må være på plass ved utskriving. I stortingsmelding nr. 47 (2008-2009) Samhandlingsreformen, defineres «samhandling» som: «uttrykk for helse og omsorgstjenestens evne til oppgavefordeling seg imellom for å nå felles mål, omforent mål, samt evnen til å gjennomføre oppgavene på en koordinert og rasjonell måte».

Sintef Helse anslår at i 2007 tilbrakte pasienter innen psykisk helsevern i Norge cirka 400-500 000 oppholdsdøgn i institusjon som utskrivingsklare. Definisjon på en «utskrivingsklar» pasient, er at denne skal være tilfredsstillende utredet og behandlet både for de tilstander som førte til innleggelse og eventuelle komplikasjoner til disse. På utskrivingstidspunktet må det foreligge et relevant tilbud i kommunen. Statistikk fra 2006-2008 viser at det til en hver tid har vært cirka 30 utskrivingsklare pasienter med tilhørighet til Trondheim kommune innlagt i psykisk helsevern.

\section{Lokale avtaler}

En gjennomgang av reformer fra de siste fem årene viser at nasjonale helsemyndigheter har vært opptatt av å bedre samhandlingen mellom statlige helseforetak og kommuner for at pasientene skal få helhetlige og koordinerte tjenester. Helse- og omsorgsdepartementet og Kommunenes Sentralforbund (KS) ble i 2007 enige om en nasjonal rammeavtale om samhandling på helse- og omsorgsområdet. Formålet er å understøtte inngåelse av lokale avtaler og bidra til bedre samhandling om brukere og pasienter som trenger både kommunale helse- og omsorgstjenester og spesialisthelsetjenester. Avtalen er evaluert av Sintef Helse og peker på flere utfordringer knyttet til utviklingen av god samhandling, blant annet likeverdighet, økonomiske forhold og systemproblemer.

\section{Helsehus}

For å finne ut om det er endringer i pasientenes sykdomstilstand som fører til økning i omsorgstjenester etter sykehusinnleggelse, eller om det er konteksten vurderinger foretas $i$, har jeg sammenlignet pasientdata fra sykehus eller DPS i 2008 med pasientdata fra etterbehandling i kommunalt helsehus i 2009. Psykiatrisk etterbehandling i kommunalt helsehus er en strategi for å finne ut om pasienten kan tilbakeføres raskere enn om pasienten ble værende på sykehus eller DPS, og samtidig sikre at de mestrer hjemmesituasjonen etter behandlingen. Pasienter som overføres 


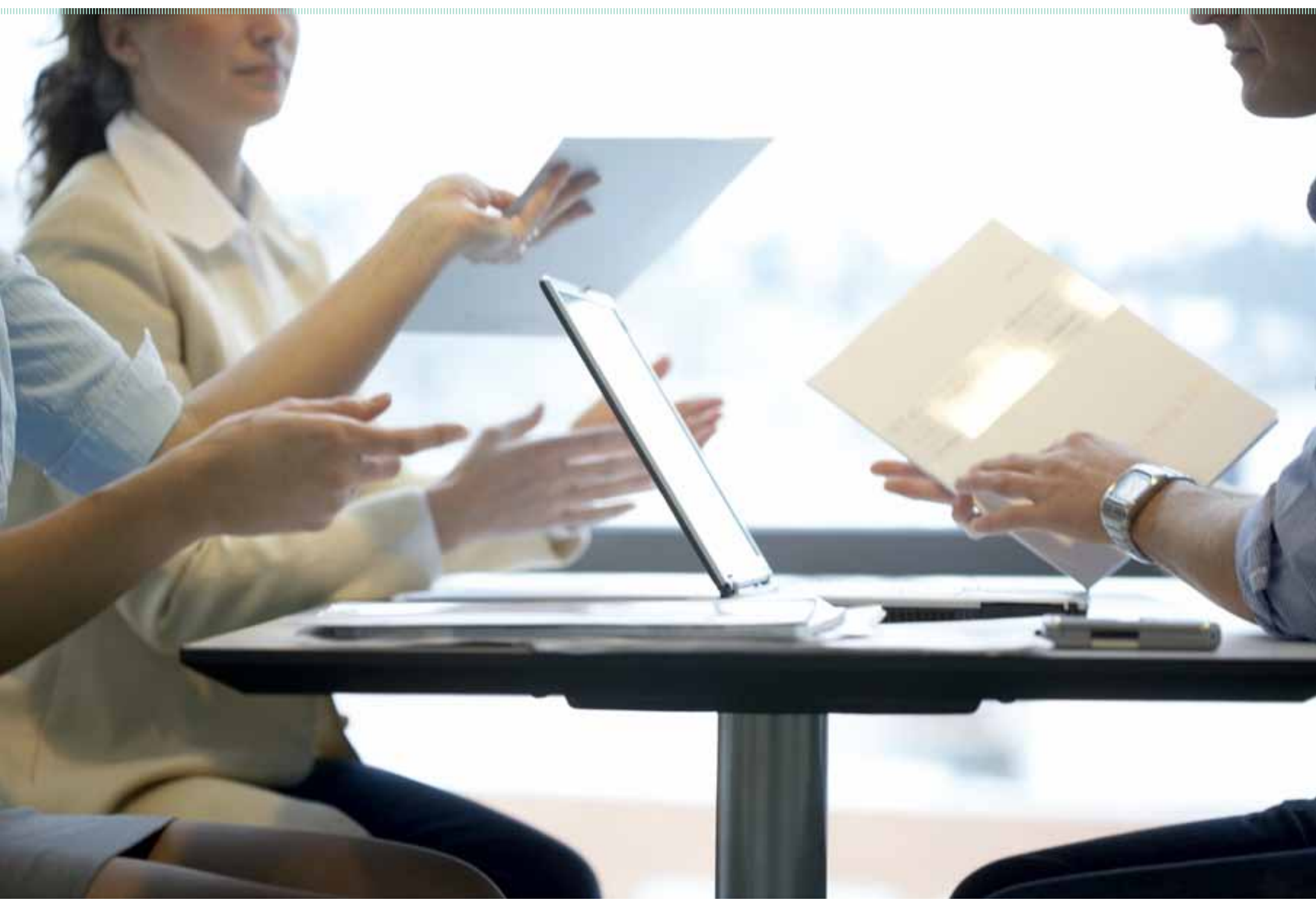

til etterbehandling i kommunalt helsehus er pasienter innlagt i psykisk helsevern som er utredet og diagnostisert, og hvor den psykiatriske behandlingsplanen kan sluttføres. Helsehus er en kommunal døgninstitusjon som tilbyr utredning eller etterbehandling, observasjon, kartlegging av hjelpebehov og rehabilitering. Oppholdets varighet for etterbehandling av psykiatriske pasienter har en varighet på inntil fire uker.

\section{Store forskjeller}

Mine funn viser store forskjeller på «ventetid» og «nivå» innenfor kommunale tjenester etter opphold på sykehus eller DPS sammenlignet med opphold i kommunalt helsehus. Mange hevder at det må forklares med forskjeller i pasientenes funksjonsevner. Da det ikke er foretatt et utvalg av pasienter som er i tråd med en vitenskapelig metode for slike undersøkelser, kan det ikke utelukkes at det kan være forskjeller i funksjonsnivå. Men kriterier for overføring av pasienter til etterbehandling inkluderer også utskrivingsklare pasienter.

For å forstå grunnlaget for fagpersonenes vurderinger av pasientenes antatte omsorgsbehov før utskriving fra sykehus eller DPS, har jeg intervjuet ledere og fagpersoner i Psykisk Helsevern og Trondheim kommune. Informanter fra spesialisthelsetjenesten sier selv at det kan være en fare for at ansatte bestiller en kommunal tjeneste som har høyere omsorgsnivå enn det pasienten i virkeligheten trenger, fordi det ikke er sykehuset som skal betale for kommunale tjenester. Sykehusansattes emosjonelle egenskaper påvirkes av pasientenes normer og verdier og fører til at de ønsker å tilfredsstille pasientens totale behov. De observerer pasientens sykdomsforløp fra «alvorlig» til «mindre alvorlig» og det kan derfor være en utfordring å se pasientenes mestringsevner. Rammene på sykehus er annerledes sammenlignet med rammene i pasientens bolig. Det er lettere å fokusere på det «syke» enn det «friske».

\section{Taus kunnskap}

Sykehusansattes bestillinger kan derfor forstås ut fra sykehusets rammer eller kontekst. I tillegg betraktes sykehusansatte som eksperter og har høy faglig legitimitet i kommunehelsetjenesten. Dersom sykehusansatte skal leve opp til omdømmet som eksperter, kan de også påta seg rollen som ekspert i å definere omsorgstjenester. Dette kan også forklares ved maktfordelingen innenfor spesialisthelsetjenesten som gir enkeltpersoner kilder til makt i kraft av sin posisjon, faglige kunnskap og ekspertise.

\section{Det er lettere å fokusere på det «syke» enn det «friske».}

En annen forklaring kan være å se på hvordan sykehusansatte helt konkret nedtegner observasjoner av pasienters omsorgsbehov og hvordan disse formidles. Sykehusansatte har fokus på den psykiatriske behandlingen og har dermed få nedskrevne data om pasientens kommunale omsorgsbehov. Observasjonene om kom-
SAMHANDLING: Kommuneansatte deltar i møter på sykehus eller i DPS for å få innblikk i pasientens omsorgsevner basert på sykehusansattes vurderinger. Berit Roald/Scanpix 
munale omsorgsbehov som formidles er derfor i hovedsak basert på «taus» kunnskap.

Trondheim kommune har i løpet av de siste årene bygget flere tilrettelagte boliger, hvor personer med en alvorlig psykisk lidelse har tilgang til personell hele døgnet. Flere utskrivingsklare pasienter har flyttet til slike boliger. Sykehusansatte har vært tilfredse med disse tilbudene. Derfor kan det være slik at sykehusansatte også bestiller omsorgstjenester som har preg av sykehustjenester, det vil si døgntjenester i institusjonslignende boliger for andre pasienter som har en alvorlig psykisk lidelse.

\section{Maktperspektiv}

Hvordan kan vi forstå kommuneansattes grunnlag for å kopiere bestillinger fra sykehusansatte?

Når fagpersonene i Trondheim kommune i hovedsak kopierer bestillingen fra spesialisthelsetjenesten kan det forklares ut fra et maktperspektiv. Fordeling av makt og oppgaver mellom partene er formelt definert gjennom helselovgivningen. Det er Trondheim kommunes fagansatte som er tildelt myndighet og oppgaven med å vurdere omsorgsbehov og fatte enkeltvedtak om kommunale tjenester, mens behandlingsansvarlige på sykehus er tildelt myndighet til å bestemme behandlingens varighet. Selv om kommuneansatte er tildelt den formelle retten til å ta beslutninger om omsorgstjenester, opplever de at «definisjonsmakta» ligger hos sykehuset. Uttalelser fra fagansatte i Trondheim kommune viser at de lar være å benytte den myndigheten de er tildelt. Dette kan forklares ut ifra både posisjonsmakt og den faglige ekspertisen som er på sykehuset eller ved DPS-et. De samme fagpersonene

\section{«Definisjonsmakta» ligger hos sykehuset.}

sier samtidig at sykehusansatte ofte bestiller bolig og døgntjeneste før de har drøftet pasientenes omsorgsbehov. Når kommuneansatte deltar i møter for å vurdere omsorgs- behov, er det for å få innblikk i pasientens omsorgsevner, basert på sykehusansattes vurderinger. Kommunens ansatte foretar ikke egne observasjoner av pasienten på sykehus eller DPS. De må derfor basere sin beslutning på sykehusansattes vurderinger. Da avtalen forplikter partene til samarbeid, kan det synes som kommuneansatte benytter en samarbeidsstrategi for å opprettholde en god relasjon til spesialisthelsetjenesten.

\section{Kunnskapsperspektiv}

En annen forklaring kan forstås ut fra et kunnskapsperspektiv. Når kommuneansatte langt på vei kopierer bestillinger fra sykehusansatte, kan dette forklares med at bestillingen av omsorgstjenester er detaljerte og dermed i mindre grad kan omformes. Når sykehusansatte bestiller en tilrettelagt bolig med tilgang til døgntjenester er det vanskelig å omforme en slik bestilling til for eksempel hjelp og tilsyn en til to dager per uke. Når sykehusansatte bestiller spesifikke kommunale omsorgstjenester i stedet for å formidle observasjoner av eventuelle omsorgsbehov, blir det ingen kunnskapsoverføring. Kommunens ansatte har også vansker med å fremsette gode faglige argumenter som går i mot sykehusansattes bestillinger, da de selv ikke har observert pasienten.

\section{Behovsvurdering}

Hvordan kan jeg forklare at pasienter som overføres til kommunalt helsehus utskrives raskere og med samme nivå på omsorgstjenester som før sykehusinnleggelsen?
Den viktigste forklaringen er etter min mening, at kommunens ansatte som over tid observerer pasientens mestringsevne også skal tildele kommunale tjenester. Kommunens ansatte er eksperter på å vurdere behov for kommunale tjenester og har kjennskap til et differensiert kommunalt tjenestetilbud. Pasientene blir observert i en kommunal kontekst som har andre rammer enn sykehus. En av informantene fra psykisk helsevern uttrykte seg slik på spørsmål om etterbehandling i Leistad: «Jeg tenker sånn at når pasienten kommer til oss (PH) så tar vi tak i det syke, mens når pasienten kommer til Leistad (helsehus) så tas det tak i det «friske»- det er virkelig ressursen - det er kjempebra».

En annen viktig faktor som må være på plass ved iverksettelsen av nytt felles tiltak, som «etterbehandling i kommunalt helsehus», er å sørge for at prosjektleder for helsehuset omsetter ideen som er beskrevet for «etterbehandling» i praksis. En god prosjektleder må være kunnskapsrik, modig og kreativ. Det blir derfor vesentlig at rutiner og retningslinjer for faglig arbeid beskrives, slik at praksisen ved etterbehandlingen kan etterprøves. Det er samtidig viktig å prioritere felles møter for ansatte og samarbeidsparter, slik at det kan «prates» om etterbehandlingskonseptet for å skape legitimitet.

\section{Målet ikke nådd}

Mine funn viser at dagens struktur for samhandling mellom fagpersoner på sykehus eller ved DPS ikke har hatt en tilsiktet virkning. Ifølge Trondheim kommunes plan for psykisk helse 2007-2010 skal ingen utskrivingsklare pasienter vente i mer enn seks uker på utskriving. Empiri viser at målet er langt unna rekkevidde. Samtidig viser mine funn en betydelig generering av omsorgstjenester og kostnader, når pasienter vurderes i forhold til kommunale omsorgsbehov på sykehus eller ved DPS. Vurdering av omsorgsbehov i en kommunal arena, gir derimot ingen vesentlige endringer i omsorgstjenester ved utskriving. Dette viser at den konteksten pasienten blir vurdert i, kan ha stor betydning for hvilke omsorgstjenester pasienten mottar etter utskriving. Jeg vil allikevel ta høyde for at funksjonsdata fra mine to undersøkelsesenheter kan være forskjellige. Målgruppen for etterbehandling i kommunalt helsehus er pasienter med alvorlige psykiske lidelser som for eksempel schizofreni og bipolare lidelser, det vil si pasienter som defineres som utskrivingsklare. Da det ikke er foretatt en randomisert undersøkelse med en kontrollgruppe, er det ikke vitenskapelig belegg for å hevde at pasientene utskrives raskere etter opphold i kommunalt helsehus.

\section{Konkrete tiltak}

På bakgrunn av mine funn foreslår jeg fire konkrete tiltak for å effektivisere samhandlingen mellom kommune- og spesialisthelsetjenesten omkring utskrivingsklare pasienter i psykisk helsevern. Den første er å avvikle brukermøter på sykehus eller ved DPS som arena for å vurdere hvilke omsorgstjenester som må være på plass etter at sykehusbehandlingen er avsluttet. Den andre anbefalingen er å videreutvikle kommunalt helsehus som arena for kartlegging av behov for kommunale tjenester og som felles læringsarena for ansatte både i kommune- og spesialisthelsetjenesten. Jeg vil også anbefale at leder eller fagansvarlig ved kommunalt helsehus får kompetanse som prosjektleder. Til sist foreslår jeg at prosjekt «etterbehandling i kommunalt helsehus» bør evalueres med bakgrunn i vitenskapelig metode. Evalueringen må inneholde indikatorer som sammenligner pasientdata, brukertilfredshet og samfunnskostnader med dagens modell for samhandling. Etter en slik vitenskapelig evaluering kan vi fastslå om etterbehandling i kommunalt helsehus gir et tilsiktet resultat. IIII 